\title{
Detecting changes in rainfall pattern and seasonality index vis-à-vis increasing water scarcity in Maharashtra
}

\author{
Pulak Guhathakurta* and Elizabeth Saji \\ India Meteorological Department, Shivajinagar, Pune 411 005, India. \\ *Corresponding author. e-mail: pguha_imd@yahoo.co.in
}

\begin{abstract}
Knowledge of mean rainfall and its variability of smaller spatial scale are important for the planners in various sectors including water and agriculture. In the present work, long rainfall data series (19012006) of districts of Maharashtra in monthly and seasonal scales are constructed and then mean rainfall and coefficient of variability are analyzed to get the spatial pattern and variability. Significant long term changes in monthly rainfall in the district scale are identified by trend analysis of rainfall time series. The seasonality index which is the measure of distribution of precipitation throughout the seasonal cycle is used to classify the different rainfall regime. Also long term changes of the seasonality index are identified by the trend analysis. The state Maharashtra which is to the northwest of peninsular India is highly influenced by the southwest monsoon and the state is facing water scarcity almost every year. This study will help to find out possible reason for the increasing water scarcity in Maharashtra.
\end{abstract}

\section{Introduction}

Geographical location of Maharashtra is such that it is subjected to different types of climatic features. Due to the varied topographical climatological features, India Meteorological Department divided the state into four meteorological subdivisions. The meteorological sub-division Konkan and Goa is to the extreme west, elongated northsouth along the west coast of India. Due to this topographical feature, the region receives very high rainfall during monsoon season. The Vidarbha region is to the extreme east of the state. The mean monsoon or annual rainfall of this region is less than that of Konkan and Goa but more than the other two sub-divisions. The other two subdivisions, viz., Madhya Maharashtra and Marathwada have almost similar rainfall pattern although Madhya Maharashtra has a slightly higher mean monsoon or annual rainfall. The rainfall patterns have high intraseasonal variability. Also there is high spatial variability of rainfall over districts of Maharashtra. It has been reported by many researchers (Guhathakurta et al. 2011; Sinharay and Srivastava 2000) about increasing trends of heavy rainfall events and also of total rainfall over Madhya Maharashtra and Konkan and Goa. Due to the increased number of disaster events and its high impact on the economic and human life, it is necessary for the district administration to have district rainfall climatology and information about temporal variability of rainfall at the district levels for better disaster management and water resource management and planning. However, so far there has been no in-depth study on district rainfall climatology, its variability and the changing pattern of rainfall using a long period of data. The reason is the absence of long period district rainfall series. In the present paper, we have presented monthly rainfall series of all the 35 districts of Maharashtra for the period 1901-2006. The mean rainfall pattern and the variability of four seasons and annual

Keywords. Water scarcity; climate change; trends; seasonality index; Maharashtra. 
rainfall for each of the 35 districts of Maharashtra are presented. This information is very useful to the agriculture and water sectors of this state. The study aims to find the changing pattern of rainfall over Maharashtra in the district scale which may have an impact on increasing extreme rainfall events and floods over Maharashtra.

The distribution of precipitation throughout the seasonal cycle is as important as the total annual amount of monthly or annual precipitation while evaluating its impact on hydrology, ecology, agriculture or in water use. The seasonal distribution of precipitation is the result of revolution of the Earth resulting in the unequal heating of the Earth's surface over the year and thus resulting in the atmospheric general circulation. The time and duration of the seasons of high precipitation at a place or watershed is most important for the planning and design of agriculture or water management. The distribution of rainfall through the season or year plays an important role in recharging the ground water. It is very important to identify the historical changes in the mean annual precipitation. But even in the absence of changes in annual total precipitation, changes in the seasonal receipt of precipitation greatly affect partitioning of water into runoff, evapotranspiration and infiltration and thus flood forecasting, stream discharge and ecosystem responses (Groisman et al. 2001; Epstein et al. 2002; Rosenberg et al. 2003; Xiao and Moody 2004; Small et al. 2006). The changing pattern of rainfall is also investigated by computing seasonality index of rainfall. The relative seasonality of rainfall represents the degree of variability in monthly rainfall throughout the year (Walter 1967; Walsh and Lawer 1981; Livada and Asimakopoulos 2005; Adejuwon 2012). Spatial distribution of precipitation seasonality in the United States was studied by Finkelstein and Truppi (1991). Markham (1970) has proposed a quantities technique for measuring precipitation seasonality based on vector analysis. The understanding of seasonality pattern of precipitation and also identifying changes in seasonality index is very useful for agricultural planning.

The seasonality index was computed for all the 35 districts for the period 1901-1950 and 19512000. The changes in the seasonality index are noticed almost in all the districts of Maharashtra.

\section{Data and methodology}

\subsection{Data construction}

Monthly rainfall data of around 335 raingauge stations of the state of Maharashtra for the period 1901-2006 are collected from the National Data
Table 1. Availability of rainfall data for the construction and analysis of district rainfall series.

\begin{tabular}{|c|c|c|c|}
\hline No. & District & Availability & Missing years \\
\hline 1 & Ahmednagar & $1901-2004$ & \\
\hline 2 & Akola & $1901-2006$ & \\
\hline 3 & Amraoti & 1901-2006 & \\
\hline 4 & Aurangabad & 1901-2006 & \\
\hline 5 & Bhandara & $1901-2005$ & 1964,1965 \\
\hline 6 & Beed & 1901-2004 & 1941 \\
\hline 7 & Mumbai city & $1901-2006$ & 1922 \\
\hline 8 & Buldhana & 1901-2006 & \\
\hline 9 & Chandrapur & 1901-2006 & \\
\hline 10 & Dhulia & 1901-2005 & \\
\hline 11 & Jalgaon & 1901-2006 & \\
\hline 12 & Raigarh & 1901-2006 & \\
\hline 13 & Kolhapur & $1901-2006$ & \\
\hline 14 & Nagpur & 1901-2006 & \\
\hline 15 & Nanded & 1901-2006 & \\
\hline 16 & Nasik & 1901-2006 & \\
\hline 17 & Osmanabad & $1901-2006$ & 2005 \\
\hline 18 & Parbhani & 1913-2006 & \\
\hline 19 & Pune & 1901-2006 & \\
\hline 20 & Ratnagiri & $1901-2006$ & \\
\hline 21 & Sangli & 1901-2006 & \\
\hline 22 & Satara & 1901-2006 & \\
\hline 23 & Solapur & 1901-2006 & \\
\hline 24 & Thane & 1901-2006 & \\
\hline 25 & Yeotmal & 1901-2006 & \\
\hline 26 & Wardha & $1901-2006$ & 2005 \\
\hline 27 & Latur & $1951-2006$ & 1952,1967 \\
\hline 28 & Gadchiroli & $1901-2004$ & \\
\hline 29 & Jalna & $1951-2004$ & \\
\hline 30 & Sindhudurg & $1901-2006$ & \\
\hline 31 & Nandurbar & $1901-2004$ & \\
\hline 32 & Gondia & 1901-2006 & \\
\hline 33 & Hingoli & 1931-2004 & 1989 \\
\hline 34 & Washim & 1901-2006 & 2005 \\
\hline 35 & Mumbai suburban & 1901-1989 & $\begin{array}{c}1916,1952,1953, \\
1967,1976\end{array}$ \\
\hline
\end{tabular}

Centre of India Meteorological Department, Pune. Monthly rainfall series of all the 35 districts of Maharashtra are then computed by arithmetic mean of the monthly rainfall of the stations under each district. Table 1 gives the status of availability of monthly rainfall data of each district so computed. Basic statistical properties are computed for the monthly rainfall time series of 35 districts and all the 12 months.

\subsection{Least square linear regression}

The least square linear regression is used to examine the existence of trend in the time series data 
Table 2. Seasonality index (SI) classes and the associated different rainfall regime.

\begin{tabular}{ll}
\hline Rainfall regime & $\begin{array}{c}\text { Seasonality } \\
\text { index (SI) }\end{array}$ \\
\hline Very equable & $\leq 0.19$ \\
Equable but with a definite wetter season & $0.20-0.39$ \\
Rather seasonal with a short drier season & $0.40-0.59$ \\
Seasonal & $0.60-0.79$ \\
Markedly seasonal with a long drier season & $0.80-0.99$ \\
Most rain in 3 months or less & $1.00-1.19$ \\
Extreme, almost all rain in $1-2$ months & $\geq 1.20$ \\
\hline
\end{tabular}

and the statistics used for testing the significance is the Student's $t$-distribution:

$$
t=r \sqrt{\frac{N-2}{1-r^{2}}}
$$

where $r$ is the Pearson's correlation coefficient of sample size $N$.

\subsection{Seasonality index}

Seasonality index helps in identifying the rainfall regimes based on the monthly distribution of rainfall. In order to define the seasonal contrasts, the seasonality index $(\overline{S I})$ (Walsh and Lawer 1981; Kanellopoulou 2002), which is a function of mean monthly and annual rainfall, is computed using the following formula:

$$
\overline{S I}=\frac{1}{\bar{R}} \sum_{n=1}^{12}\left|X_{n}-\frac{\bar{R}}{12}\right|
$$

where $X_{n}$ is the mean rainfall of month $n$ and $\bar{R}$ is the mean annual rainfall. Theoretically, the $\overline{S I}$ can vary from zero (if all the months have equal rainfall) to 1.83 (if all the rainfall occurs in one month). Table 2 shows the different class limits of SI and representative rainfall regimes (Kanellopoulou 2002). Though the method uses the distribution of rainfall for all the 12 months, the index as table identifies the seasonal pattern when the value is more than 0.6 .

To investigate the changes in rainfall pattern we have computed the seasonality index of all the 35 districts for the periods 1901-1950 and 1951-2006 and compared the changes between these periods.

\section{Results and discussions}

\subsection{Statistical analysis and spatial variation of rainfall of the districts of Maharashtra}

Figure 1 shows mean rainfall (in $\mathrm{mm}$ ) for the districts of Maharashtra for the four seasons.
During the winter season (January-February), all the districts of central and western parts of the state received very low rainfall (even much less than $10 \mathrm{~mm}$ ). The districts in the eastern part received rainfall around $20-30 \mathrm{~mm}$ with maximum value of $35.9 \mathrm{~mm}$ in Bhandara district. The maximum rainfall zone has shifted from eastern parts of the state to south western parts in pre-monsoon season (March-May) season. The maximum rainfall of $87.0 \mathrm{~mm}$ is being received by Kolhapur district. Mean rainfall for the most of the districts are between 20 and $30 \mathrm{~mm}$ during this season. Both in monsoon and post-monsoon seasons, maximum rainfall is received by Ratnagiri district. The changing pattern of maximum rainfall zone, i.e., initially at the eastern parts, then southern parts in pre-monsoon and slightly northern movement in monsoon season and remaining there in postmonsoon is clearly seen by comparing a, b, c and $\mathrm{d}$ of figure 1. Mean annual rainfall pattern over the districts of Maharashtra is shown in figure 2 . In addition to mean rainfall pattern, the knowledge of variability of rainfall is of great use for hydrological planning and management. Figure 3 shows the spatial distribution of coefficient of variation for the four seasons while figure 4 is for annual rainfall. Very less amount of rainfall is being received during the winter season and the variability is very high in all the districts of Maharashtra. Maximum variability (420.8\%) is over Ahmednagar and the lowest variability (106.1) is over Nagpur. Variability decreased as the monsoon set in and again it increased in the post-monsoon season. During monsoon season, in spite of very high rainfall, coefficient of variability of monsoon rainfall is very high in Mumbai ( $>35 \%)$. The mean rainfall pattern over the districts of Maharashtra during four seasons can be physically explained with weather systems in India. During winter seasons, country (mostly northern parts) gets rainfall due to western disturbances and southern parts due to easterly waves. As a result, eastern parts of Maharashtra gets some rain whereas western parts receive negligible amount of rain. During the premonsoon season, most of the parts of the country along with Maharashtra get rain due to convective activities and thus mean rainfall are almost similar in the districts of Maharashtra. During monsoon season, western parts of Maharashtra get excessive rain due to strong westerlies from Arabian Sea and the presence of offshore trough whereas eastern parts of Maharashtra get rain mostly from the Bay of Bengal branches of monsoon current. The mean rainfall over Madhya Maharashtra is thus less than the western and eastern parts. In post-monsoon season, southern parts of the state get rain from the westerly waves and northeast monsoon to some extent. 


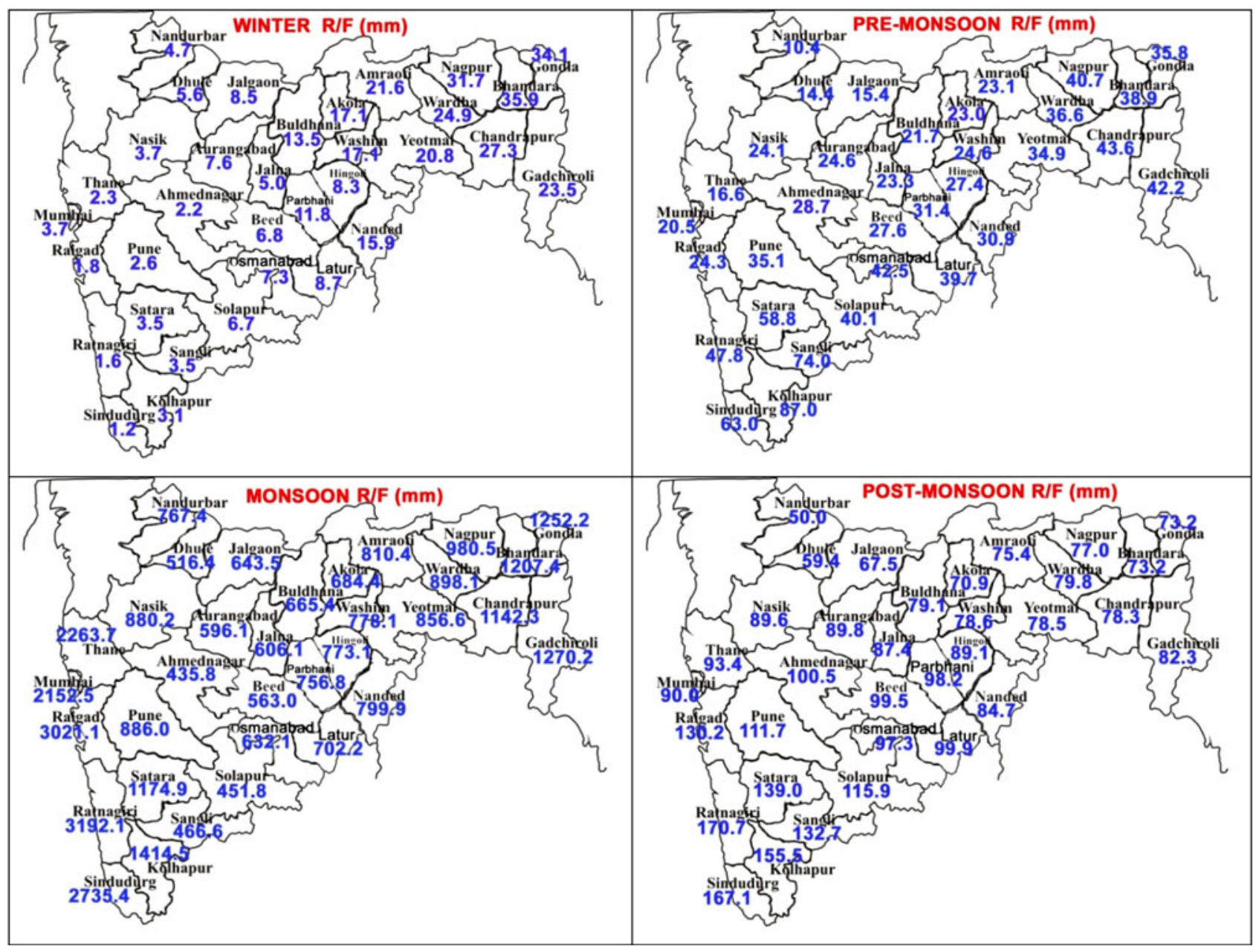

Figure 1. Mean rainfall $(\mathrm{mm})$ over the districts of Maharashtra for the four seasons.

\subsection{Trends in the monthly, seasonal and annual rainfall pattern}

The study by Guhathakurta and Rajeevan (2008) has revealed the existence of significant changes in the rainfall pattern over meteorological subdivisions of India for the monsoon months and seasons. However, the changes in smaller scales are required to be identified for better disaster management and also for climate change studies. Figure 5 shows the trends in the monthly rainfall over the districts of Maharashtra. Different levels of significance, i.e., 99\%, 95\% and 90\% obtained in trend analysis are shown in different colours. There was no significant trend in the rainfall in any districts of Maharashtra for the months of November and December. No district has reported increasing trend in rainfall for the months February, March, April and May (except Latur in May). The significant decreasing trend in rainfall activities starts from January and extends up to May indicating a major shift in the rainfall pattern. The time period or duration of rainfall activities are therefore confined to the monsoon months only, over Maharashtra region which may have impact in

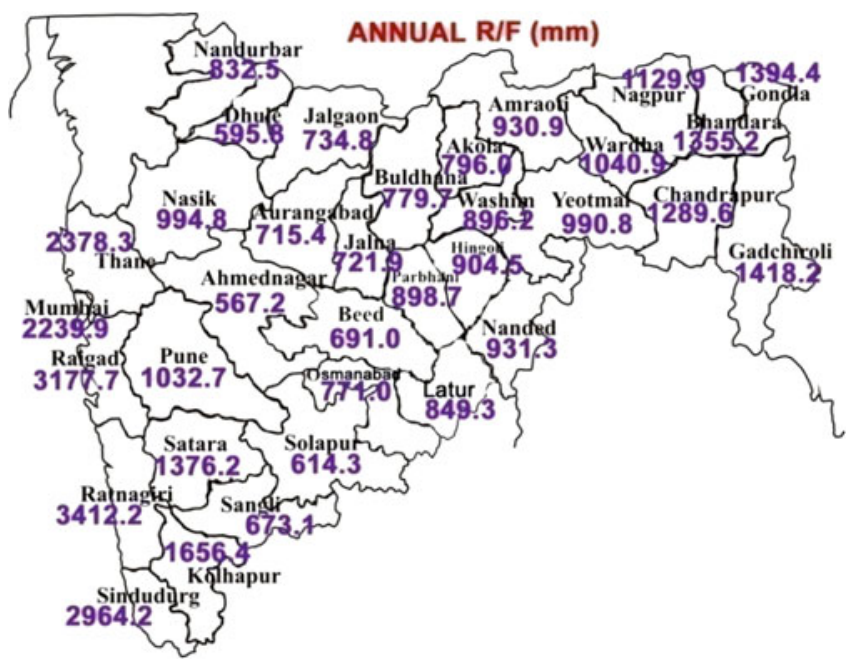

Figure 2. Mean annual rainfall ( $\mathrm{mm})$ over the districts of Maharashtra.

the agricultural activities for the crops during non-monsoon months over the region.

Table 3 shows the details of the result of trend analysis in monthly, seasonal and annual rainfall 


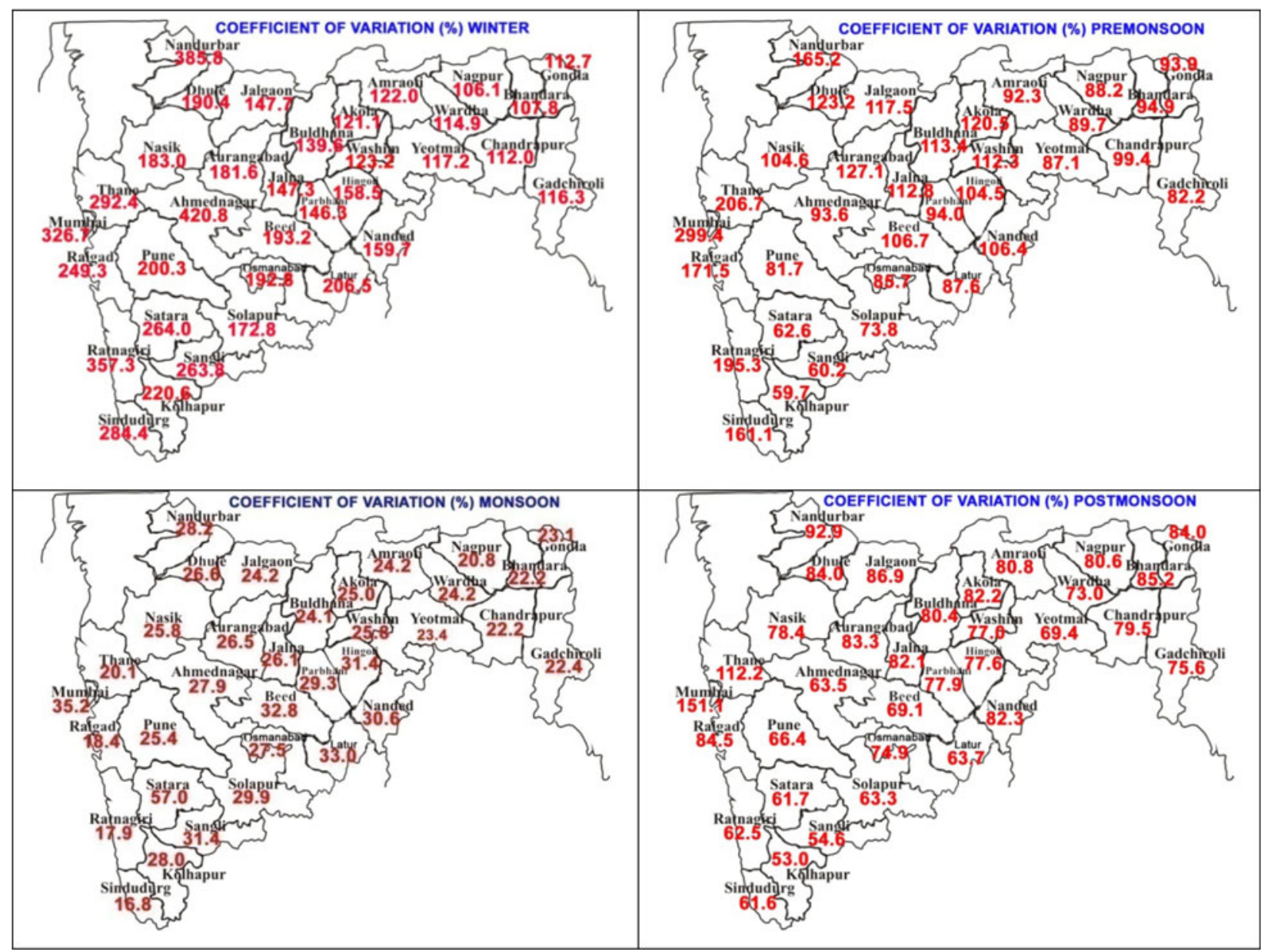

Figure 3. Distribution of coefficient of variation (\%) of rainfall over the districts of Maharashtra during the four seasons.

for the districts of Maharashtra. The values shown in the tables are increase/decrease in rainfall in $\mathrm{mm} /$ year and different colours indicate the level of significance. In January, eight districts had shown significant decrease in rainfall. Except Kolhapur, all these districts are in the north and central parts of the state. In February, the areas of decreasing trends had shifted mostly to the northeastern parts with 15 districts reporting decreasing trends. In March, only three coastal districts, viz., Mumbai, Thane, Raigad; in April, six districts and in May, three districts had shown significant decrease in rainfall. Around middle of the year particularly from June, monthly rainfall had shown increasing trends in some districts and had reduced decreasing trends. In June, one district, viz., Latur; in July, six districts and in September, six districts had shown significant decrease in rainfall activity.

Maximum areas of the state shows increasing trends in the months of August (23 districts) and October (13 districts). Five districts in June and three districts in July had shown significant increasing trends. There were no significant

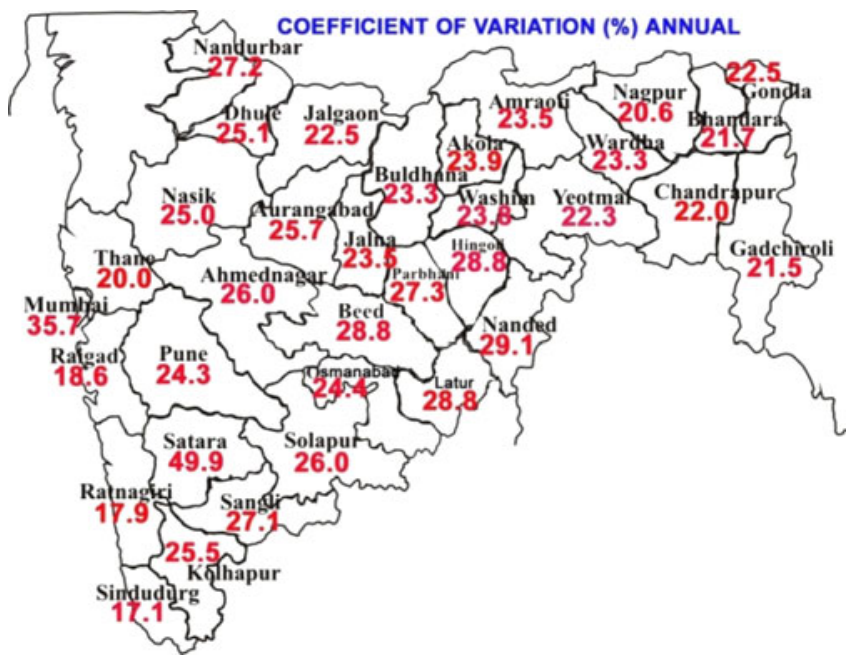

Figure 4. Distribution of coefficient of variation (\%) over the districts of Maharashtra of annual rainfall.

decreasing trends in any district rainfall for the months of August and October.

These results are reflected in the seasonal and annual rainfall trends (figure 6). Both in winter and 


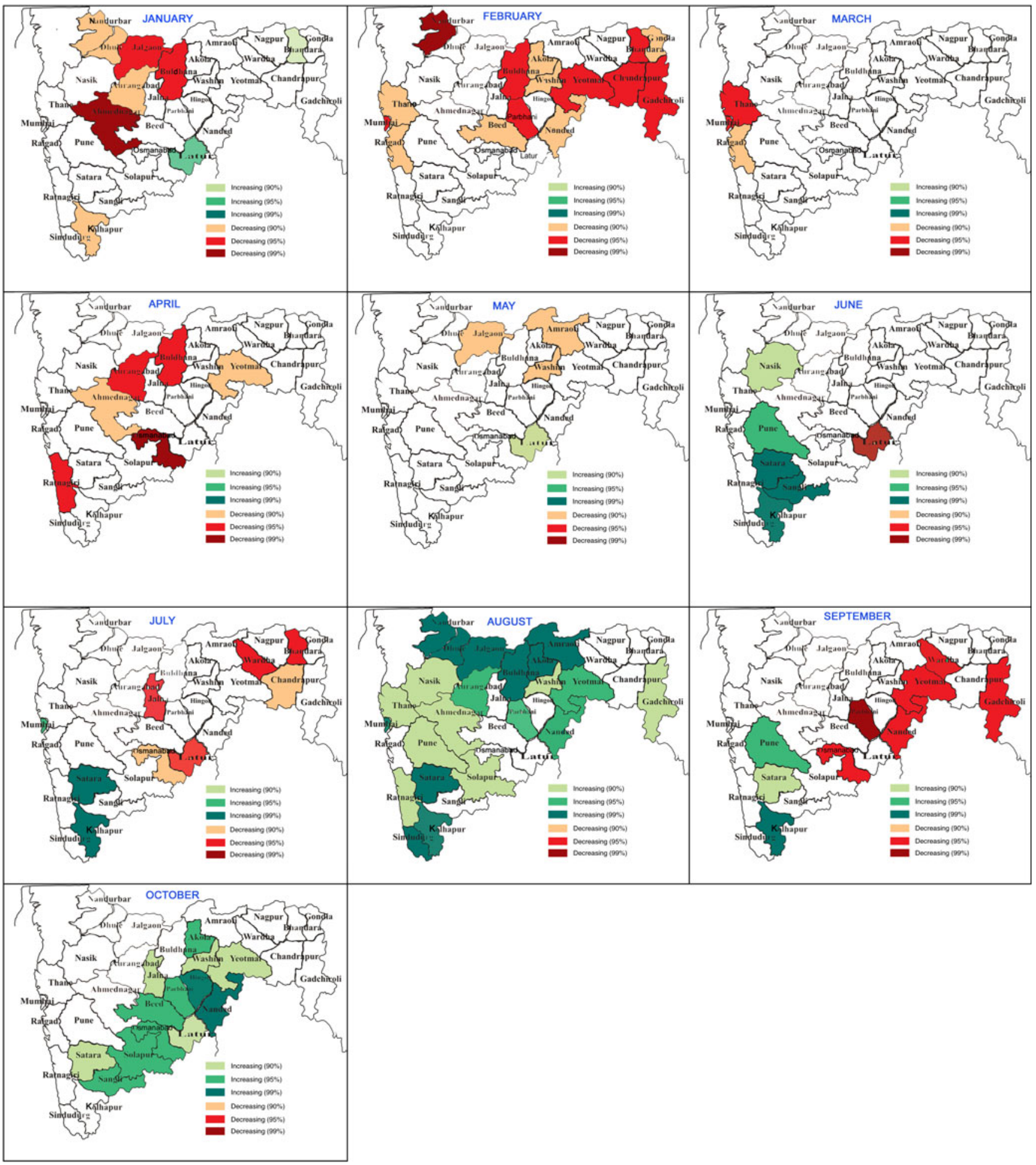

Figure 5. Trends in the monthly rainfall over the districts of Maharashtra. There is no significant trend in the rainfall in any districts of Maharashtra for the month of November and December.

pre-monsoon seasons, no district except Latur has shown increasing trend in rainfall. Fourteen districts in winter and three districts in pre-monsoon seasons have shown significant decreasing trends. During monsoon season, 10 districts all along the western coast/western parts of Maharashtra, viz., Nandurbar, Dhule, Nasik, Pune, Mumbai, Raigad, Satara, Kolhapur and Sindhudurg have showed significant increase in rainfall while only four districts, viz., Latur, Bhandara, Osmanabad and Wardha 
Table 3. Increase/decrease in rainfall in mm/year for the districts of Maharashtra.

\begin{tabular}{|c|c|c|c|c|c|c|c|c|c|c|c|c|c|c|c|c|c|c|}
\hline SI. no. & Districts & Jan & Feb & Mar & Apr & May & Jun & Jul & Aug & Sep & Oct & Nov & Dec & Ann & Win & Pre & Mon & Post \\
\hline 1 & Ahmednagar & -0.07 & -0.01 & -0.01 & -0.06 & 0.03 & 0.05 & -0.06 & 0.33 & -0.08 & 0.29 & -0.12 & 0.01 & 0.30 & -0.08 & -0.03 & 0.24 & 0.18 \\
\hline 2 & Akola & -0.05 & -0.08 & 0.07 & -0.04 & -0.02 & 0.14 & -0.28 & 0.84 & -0.26 & 0.33 & -0.08 & -0.07 & 0.54 & -0.11 & 0.02 & 0.45 & 0.21 \\
\hline 3 & Amraoti & -0.05 & -0.09 & -0.01 & -0.04 & -0.09 & -0.12 & -0.14 & 1.01 & -0.30 & 0.16 & -0.08 & -0.02 & 0.24 & -0.13 & -0.14 & 0.45 & 0.08 \\
\hline 4 & Aurangabad & -0.07 & -0.03 & -0.01 & -0.06 & -0.04 & -0.05 & -0.23 & 0.57 & -0.15 & 0.28 & -0.05 & 0.01 & -0.17 & -0.10 & -0.10 & -0.22 & 0.23 \\
\hline 5 & Beed & -0.04 & -0.05 & -0.03 & -0.03 & 0.06 & 0.25 & -0.02 & 0.39 & -0.42 & 0.42 & -0.13 & 0.03 & 0.69 & -0.06 & 0.02 & 0.21 & 0.36 \\
\hline 6 & Bhandara & 0.15 & -0.19 & -0.02 & -0.10 & -0.02 & -0.45 & -1.05 & -0.57 & -0.53 & 0.11 & 0.00 & 0.05 & -2.70 & -0.02 & -0.11 & -2.61 & 0.20 \\
\hline 7 & Mumbai City & -0.04 & -0.03 & -0.01 & 0.00 & 0.05 & 0.74 & 1.99 & 2.61 & 0.79 & 0.23 & -0.04 & 0.01 & 6.48 & -0.07 & 0.05 & 6.03 & 0.20 \\
\hline 8 & Mumbai Suburb & -0.06 & -0.02 & -0.02 & 0.00 & -0.10 & 2.08 & 2.39 & 2.84 & 0.76 & -0.03 & -0.04 & 0.01 & 6.18 & -0.08 & -0.11 & 6.80 & 0.01 \\
\hline 9 & Buldhana & -0.09 & -0.07 & 0.01 & -0.07 & -0.06 & -0.10 & -0.36 & 0.91 & -0.38 & 0.24 & -0.10 & -0.08 & -0.15 & -0.16 & -0.10 & 0.07 & 0.10 \\
\hline 10 & Chandrapur & 0.06 & -0.18 & -0.03 & -0.01 & 0.04 & -0.03 & -0.69 & 0.53 & -0.54 & 0.24 & -0.10 & -0.08 & -0.90 & -0.10 & 0.02 & -0.81 & 0.18 \\
\hline 11 & Dhulia & -0.06 & -0.01 & 0.00 & 0.00 & -0.01 & 0.26 & 0.15 & 0.63 & 0.04 & 0.09 & -0.08 & 0.01 & 1.02 & -0.07 & 0.00 & 1.08 & 0.06 \\
\hline 12 & Gadchiroli & -0.01 & -0.17 & -0.05 & -0.09 & -0.01 & 0.42 & -0.29 & 0.91 & -0.70 & 0.17 & -0.06 & 0.02 & 0.16 & -0.16 & -0.12 & 0.35 & 0.18 \\
\hline 13 & Gondia & 0.10 & -0.15 & 0.01 & -0.05 & 0.01 & -0.12 & -0.31 & 0.20 & -0.03 & 0.05 & -0.08 & 0.03 & -0.36 & -0.03 & -0.01 & -0.32 & 0.04 \\
\hline 14 & Hingoli & 0.07 & -0.03 & -0.03 & -0.11 & -0.06 & 0.30 & -0.49 & 0.56 & 0.01 & 0.77 & -0.19 & 0.01 & 0.51 & 0.04 & -0.16 & 0.38 & 0.64 \\
\hline 15 & Jalgaon & -0.07 & 0.00 & 0.01 & -0.02 & -0.09 & 0.04 & -0.28 & 0.96 & -0.24 & 0.14 & -0.09 & 0.01 & 0.15 & -0.07 & -0.08 & 0.27 & 0.10 \\
\hline 16 & Jalna & 0.01 & -0.01 & 0.03 & -0.03 & 0.06 & 0.19 & -0.94 & -0.03 & -0.38 & 0.73 & 0.00 & 0.12 & -0.25 & 0.01 & 0.11 & -1.16 & 0.97 \\
\hline 17 & Kolhapur & -0.03 & 0.00 & -0.03 & -0.07 & 0.02 & 2.27 & 2.24 & 2.76 & 0.70 & 0.27 & -0.18 & -0.05 & 8.15 & -0.03 & -0.03 & 7.97 & 0.12 \\
\hline 18 & Latur & 0.20 & 0.02 & 0.06 & -0.01 & 0.34 & -1.04 & -1.39 & -0.41 & -0.58 & 0.74 & -0.07 & 0.02 & -3.23 & 0.23 & 0.45 & -4.36 & 0.78 \\
\hline 19 & Nagpur & 0.10 & -0.11 & 0.02 & -0.08 & -0.05 & -0.32 & -0.17 & 0.04 & -0.33 & 0.12 & -0.03 & 0.02 & -0.80 & 0.01 & -0.09 & -0.79 & 0.15 \\
\hline 20 & Nanded & 0.04 & -0.11 & -0.04 & -0.02 & -0.02 & 0.01 & 0.25 & 0.98 & -0.81 & 0.60 & -0.04 & -0.05 & 0.79 & -0.06 & -0.06 & 0.51 & 0.55 \\
\hline 21 & Nandurbar & -0.10 & -0.02 & -0.01 & 0.00 & 0.00 & 0.47 & 0.24 & 1.21 & 0.08 & 0.04 & -0.04 & -0.02 & 1.88 & -0.12 & 0.00 & 2.03 & 0.01 \\
\hline 22 & Nasik & -0.03 & -0.01 & 0.00 & -0.02 & -0.09 & 0.54 & -0.02 & 0.56 & 0.18 & 0.12 & 0.00 & 0.01 & 1.04 & -0.03 & -0.10 & 1.26 & 0.10 \\
\hline 23 & Osmanabad & -0.01 & -0.01 & 0.00 & -0.16 & 0.04 & -0.33 & -0.46 & -0.08 & -0.68 & 0.48 & -0.02 & -0.03 & -0.96 & -0.02 & -0.12 & -1.52 & 0.56 \\
\hline 24 & Parbhani & -0.06 & -0.09 & -0.04 & -0.01 & -0.02 & -0.19 & 0.19 & 1.09 & -1.09 & 0.60 & -0.21 & -0.05 & 0.02 & -0.14 & -0.03 & 0.01 & 0.33 \\
\hline 25 & Pune & -0.02 & -0.01 & -0.01 & -0.05 & -0.03 & 0.54 & 0.14 & 0.62 & 1.50 & 0.20 & -0.15 & 0.01 & 1.31 & -0.03 & -0.09 & 1.50 & 0.11 \\
\hline 26 & Raigarh & -0.02 & -0.01 & -0.01 & 0.00 & 0.03 & 0.88 & 0.47 & 1.54 & 0.03 & 0.21 & -0.03 & 0.03 & 3.49 & -0.03 & 0.03 & 3.30 & 0.26 \\
\hline 27 & Ratnagiri & -0.02 & -0.01 & -0.01 & -0.07 & 0.41 & 0.48 & -1.65 & 1.67 & 0.12 & 0.16 & -0.14 & 0.01 & 0.93 & -0.03 & 0.34 & 0.61 & 0.11 \\
\hline 28 & Sangli & -0.01 & 0.01 & -0.02 & -0.08 & 0.06 & 0.67 & -0.16 & 0.19 & 0.25 & 0.51 & -0.15 & -0.06 & 0.51 & -0.01 & -0.01 & 0.73 & 0.12 \\
\hline 29 & Satara & -0.04 & 0.00 & -0.01 & -0.02 & 0.02 & 1.63 & 5.80 & 2.59 & 0.58 & 0.40 & -0.14 & 0.00 & 6.00 & -0.04 & 0.01 & 5.80 & 0.32 \\
\hline 30 & Sholapur & -0.04 & -0.01 & 0.00 & -0.03 & 0.10 & 0.12 & 0.15 & 0.36 & 0.05 & 0.46 & -0.10 & -0.05 & 0.93 & -0.05 & 0.09 & 0.60 & 0.37 \\
\hline 31 & Sindhudurg & 0.00 & -0.01 & 0.00 & -0.04 & 0.21 & 0.95 & 0.48 & 2.07 & 0.30 & 0.43 & -0.17 & 0.02 & 4.52 & -0.01 & 0.20 & 4.16 & 0.32 \\
\hline 32 & Thane & -0.03 & -0.01 & -0.02 & -0.01 & -0.09 & 0.59 & -0.37 & 1.43 & 0.51 & -0.31 & -0.04 & -0.01 & 1.58 & -0.04 & -0.10 & 2.16 & -0.29 \\
\hline 33 & Wardha & 0.00 & -0.08 & 0.03 & -0.06 & -0.02 & -0.37 & -0.77 & 0.50 & -0.73 & 0.20 & -0.03 & 0.03 & -1.30 & -0.06 & -0.02 & -1.37 & 0.24 \\
\hline 34 & Washim & -0.03 & -0.09 & -0.03 & -0.07 & -0.10 & 0.24 & 0.04 & 0.60 & -0.11 & 0.34 & -0.13 & -0.02 & 0.46 & -0.10 & -0.18 & 0.57 & 0.23 \\
\hline 35 & Yeotmal & 0.03 & -0.15 & -0.03 & -0.10 & -0.06 & 0.10 & -0.26 & 0.71 & -0.61 & 0.33 & -0.09 & -0.01 & -0.12 & -0.11 & -0.16 & -0.05 & 0.27 \\
\hline
\end{tabular}

have shown significant decreasing trend. In the post-monsoon season when the rainfall is received mostly due to northeast monsoon, rainfall for the districts Osmanabad, Jalna, Hingoli, Nanded and Latur all from southeastern parts of the state have shown significant increasing trend. Latur district has shown significant increasing trend in rainfall during winter, pre-monsoon and post-monsoon seasons, but decreasing trend in monsoon season and as a result annual rainfall of Latur has decreased significantly.

Thus after analysis of district rainfall, it is found that monsoon rainfall has increased for most of the districts of Madhya Maharashtra and for only three districts of Konkan region, while for the two districts each of Marathwada and Vidarbha rainfall has decreased significantly.

\subsection{Changes in seasonality index}

The seasonality index has been computed for all the districts of Maharashtra for two different periods, viz., the first 50-year 1901-1950 and the later 50-year period 1951-2000. This will help to find the changes (if any) in the seasonality index in the last 100 years. Figure 7 shows the seasonality index during 1901-1950 and 1951-2000 periods. From table 2 , we can see that the lower seasonality index value indicates better distribution of monthly rainfall among the months of the year. The maximum seasonality index value is over Thane, Mumbai, Raigad and Ratnagiri districts in both the periods 1901-1950 and 1951-2000 and is between 1.2 and 1.3 indicating most of the rain occurred in the northern parts of west coast of Maharashtra 


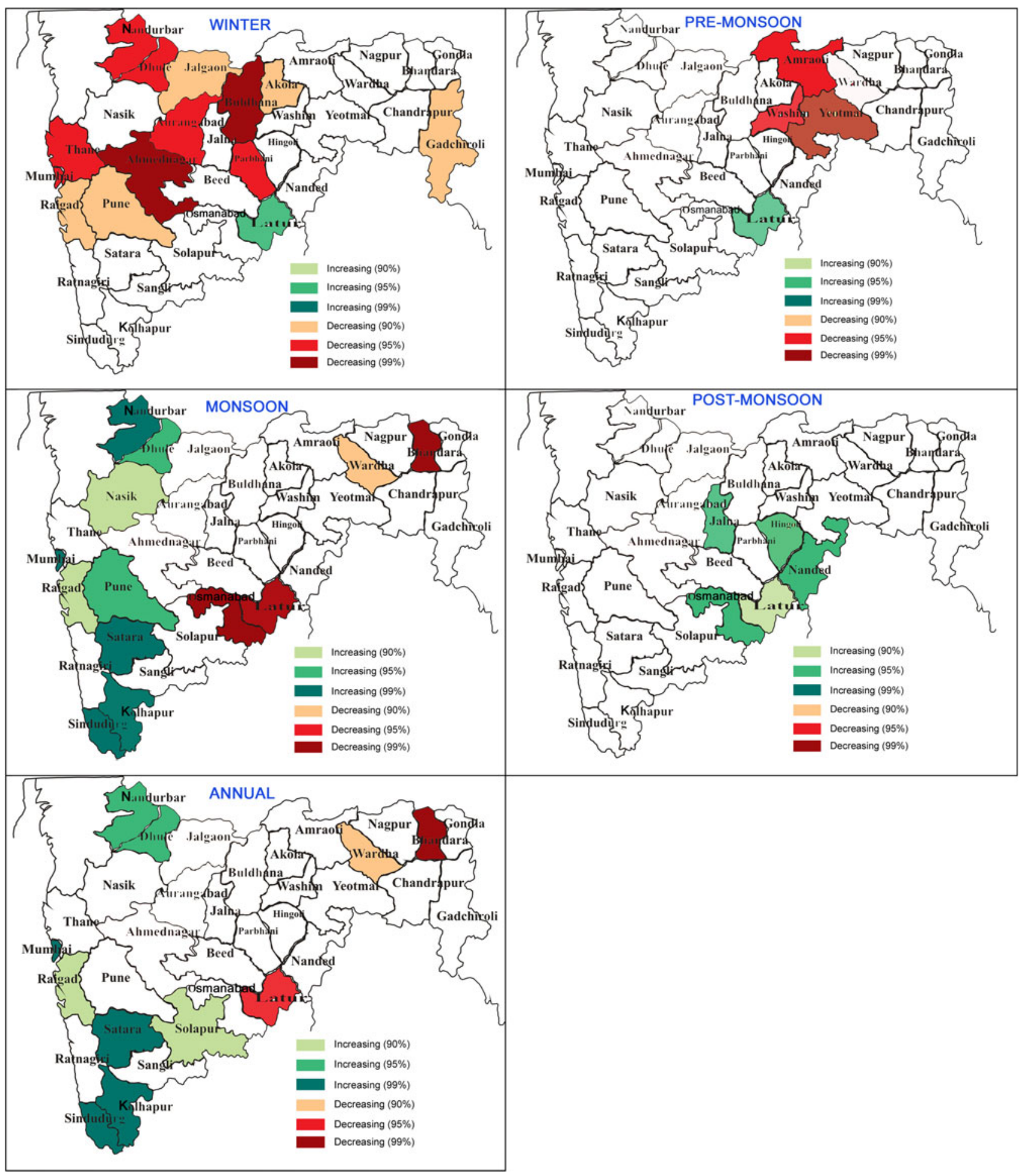

Figure 6. Trends in the seasonal and annual rainfall over the districts of Maharashtra.

in one to two months. The spatial distribution of seasonality index remained almost same in both the periods. The lower value of seasonality index was over Sangli and Solapur and was in the range $0.8-0.9$. This indicates that only in these two districts rainfall was purely seasonal and was evenly distributed in four months though the mean monsoon rainfall was less compared to other districts of Maharashtra. Rainfall of the six districts, viz., Ahmednagar, Aurangabad, Beed, Osmanabad, Amraoti and Latur was marked seasonal with rainfall evenly distributed in 3-4 months 
a

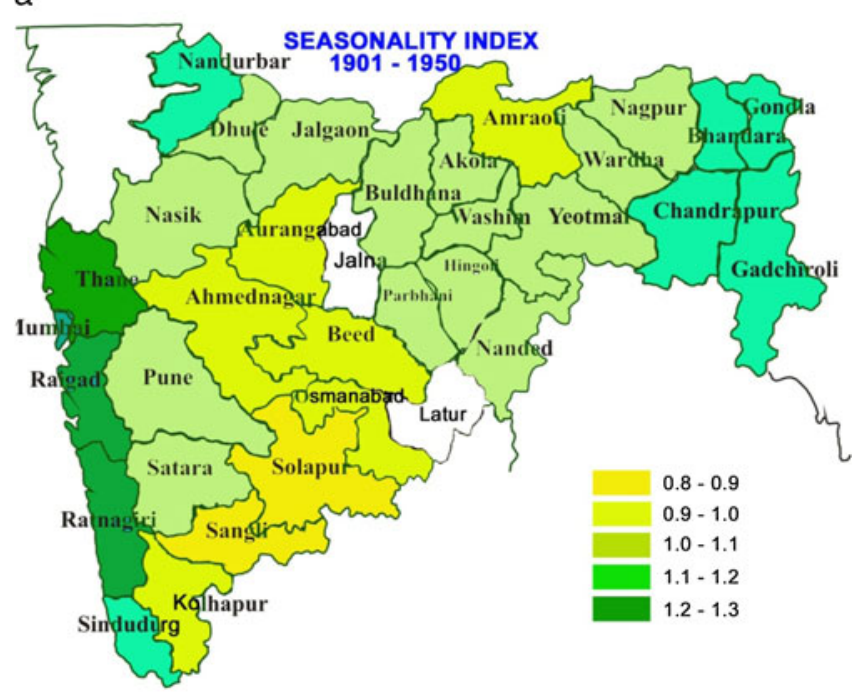

b

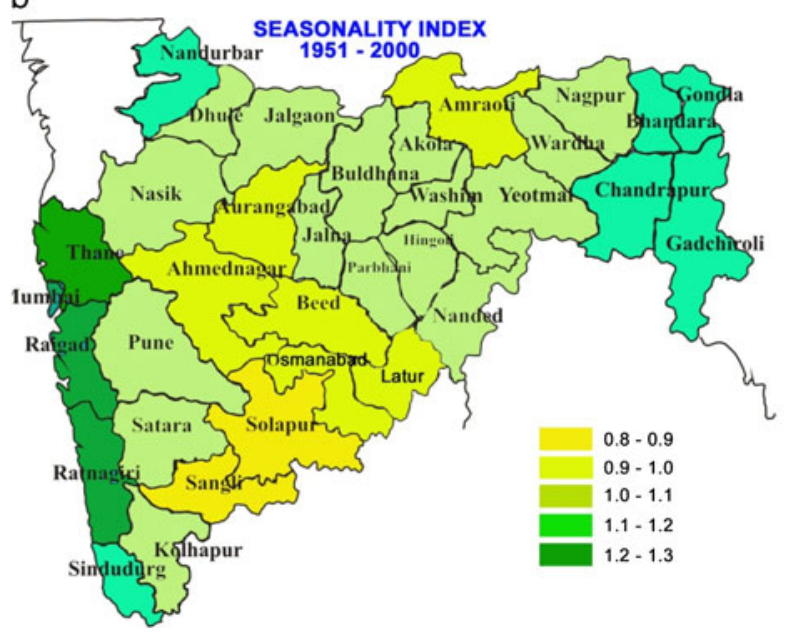

Figure 7. Values of the SI of the districts of Maharashtra during the period (a) 1901-1950 and (b) 1951-2000.

as SI was in the range $0.9-1.0$ in the period 19011950. The less availability of data for the districts Jalna and Latur caused missing SI value in figure $7(\mathrm{a})$. This pattern was almost same in the next period 1951-2000 with only changes in Kolhapur district where SI value increased to be in the range 1.0-1.1 indicating rainfall distribution in three month or less. In the six districts, viz., Nandurbar, Sindhudurg, Chandrapur, Gadchiroli, Bhandara and Gondia seasonality index value was between 1.1 and 1.2 indicating that the most rain occurred in three months or less.

As mentioned above, low value of seasonality index indicates that the type of rainfall regime with shorter dry season and high value indicates most of the rain occurs within few months (2-3 months). An increasing trend in seasonality index is thus an indicator of alarming situation for the agriculture. Though figure 7 highlights that the rainfall

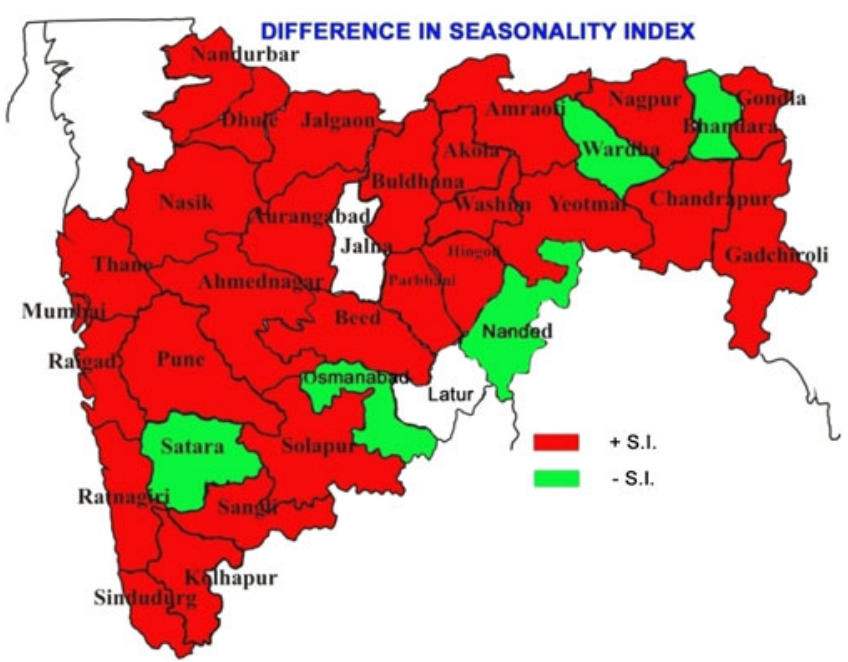

Figure 8. Changes in the SI in the period 1951-2000 from the period 1901-1950.

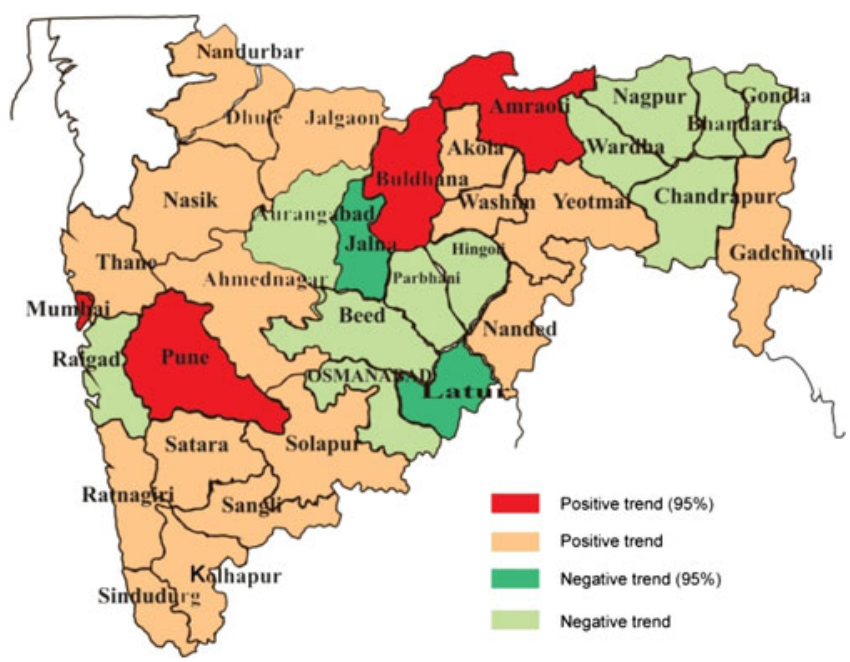

Figure 9. Trends in the SI over districts of Maharashtra.

regime was mostly similar in the periods 19011950 and 1951-2000, to identify the changes in the seasonality index, we have computed the differences in the seasonality index (figure 8) between the periods 1901-1950 and 1951-2000. The seasonality index has been increased in all the districts except Satara, Osmanabad, Nanded, Wardha and Bhandara. In order to find out whether these changes are significant or not, we have further carried out the trends in seasonality index series $S I_{k}$. The seasonality index $S I_{k}$ (Walsh and Lawer 1981; Pryor and Schoof 2008) time series for each of the districts for each year $k$ has been calculated using the formula:

$$
S I_{k}=\frac{1}{R_{k}} \sum_{n=1}^{12}\left|X_{n k}-\frac{R_{k}}{12}\right|
$$


where $x_{n k}$ is the rainfall of month $n$ of the year $k$ and $R_{k}$ is the total annual rainfall for the year $k$. The mean of seasonality index of a specific period calculated from the above equation may differ slightly with the seasonality index calculated from the mean rainfall of the period using the formula stated earlier according to Walsh and Lawer (1981) and Pryor and Schoof (2008).

Trend analysis has been done on the SI for each of the districts. Figure 9 shows the trends in the seasonility index over the districts of Maharashtra.

Table 4. Changes in the seasonality index (SI) values in 100 years and the SI values in the period 1901-1950 and 1951-2000.

\begin{tabular}{|c|c|c|c|c|}
\hline \multirow[b]{2}{*}{ Sl. no. } & \multirow[b]{2}{*}{ Districts } & \multirow{2}{*}{$\begin{array}{l}\text { SI increase } \\
\text { in } 100 \mathrm{Yr}\end{array}$} & \multicolumn{2}{|c|}{ SI value in } \\
\hline & & & $1901-1950$ & $1951-2000$ \\
\hline 1 & Ahmednagar & 0.0245 & 0.905 & 0.948 \\
\hline 2 & Akola & 0.0292 & 1.038 & 1.075 \\
\hline 3 & Amraoti & 0.0785 & 1.038 & 1.101 \\
\hline 4 & Aurangabad & -0.0065 & 0.995 & 0.995 \\
\hline 5 & Beed & -0.0377 & 0.965 & 0.979 \\
\hline 6 & Bhandara & -0.0466 & 1.123 & 1.105 \\
\hline 7 & Mumbai city & 0.0103 & 1.213 & 1.231 \\
\hline 8 & Mumbai Suburb & 0.0676 & 1.221 & 1.248 \\
\hline 9 & Buldhana & 0.0813 & 1.015 & 1.064 \\
\hline 10 & Chandrapur & -0.0020 & 1.099 & 1.110 \\
\hline 11 & Dhule & 0.0228 & 1.048 & 1.069 \\
\hline 12 & Gadchiroli & 0.0223 & 1.115 & 1.132 \\
\hline 13 & Gondia & -0.0232 & 1.122 & 1.132 \\
\hline 14 & Hingoli & -0.0023 & 1.029 & 1.067 \\
\hline 15 & Jalgaon & 0.0260 & 1.070 & 1.093 \\
\hline 16 & Jalna & -0.1520 & & 1.011 \\
\hline 17 & Kolhapur & 0.1561 & 0.990 & 1.066 \\
\hline 18 & Latur & -0.1815 & & 1.002 \\
\hline 19 & Nagpur & -0.0079 & 1.069 & 1.065 \\
\hline 20 & Nanded & 0.0179 & 1.069 & 1.033 \\
\hline 21 & Nandurbar & 0.0172 & 1.156 & 1.189 \\
\hline 22 & Nasik & 0.0077 & 1.088 & 1.093 \\
\hline 23 & Osmanabad & -0.0557 & 0.999 & 0.984 \\
\hline 24 & Parbhani & -0.0032 & 1.015 & 1.034 \\
\hline 25 & Pune & 0.0621 & 1.025 & 1.055 \\
\hline 26 & Raigarh & -0.0108 & 1.230 & 1.237 \\
\hline 27 & Ratnagiri & 0.0023 & 1.205 & 1.209 \\
\hline 28 & Sangli & 0.0503 & 0.805 & 0.849 \\
\hline 29 & Satara & 0.0596 & 1.024 & 1.010 \\
\hline 30 & Solapur & 0.0066 & 0.869 & 0.930 \\
\hline 31 & Sindhudurg & 0.0053 & 1.177 & 1.179 \\
\hline 32 & Thane & 0.0228 & 1.220 & 1.250 \\
\hline 33 & Wardha & -0.0135 & 1.064 & 1.056 \\
\hline 34 & Washim & 0.0551 & 1.042 & 1.098 \\
\hline 35 & Yeotmal & 0.0326 & 1.050 & 1.073 \\
\hline
\end{tabular}

$\uparrow$ significant; $\uparrow$ not significant; $\downarrow$ significant; $\quad \downarrow$ not significant
Significant increasing trends are seen in Mumbai, Pune, Buldhana and Amraoti districts. SI has also showed increasing trend for the districts of Thane, Nandurbar, Dhule, Jalgaon, Nasik, Ahmednagar, Solapur, Satara, Sangli, Kohlapur, Ratnagiri, Sindhudurg, Akola, Washim, Yeotmal, Nanded and Gadchiroli. Significant decreasing trend is good as it indicates that increase in even distribution in the monthly scale are being noticed in Jalna and Latur (significant) while the districts, Raigad, Aurangabad, Beed, Osmanabad, Parbhani, Hingoli, Wardha, Nagpur, Bhandara, Gondia and Chandrapur have shown decreasing trend.

Table 3 summarized the values of the seasonality index increase/decrease in 100 years obtained by linear trend analysis of seasonality index time series and also displays the values of the seasonality index of 35 districts and for the periods 1901-1950 and 1951-2000 calculated by the formula mentioned in the mythology from the mean monthly rainfall (table 4$)$.

\section{Conclusions}

We have analyzed the rainfall data of more than 100 years over Maharashtra, a large state in western India which plays a significant role in the industrial and agricultural contribution in the overall growth of the country. The analysis includes variability of rainfall, trends in rainfall pattern and changes in spatial and temporal patterns of seasonality index. The impact of climate changes on temporal and spatial patterns over smaller spatial scales is clearly noticed in this analysis. Significant decreasing trends in monthly rainfall are being observed in many areas (districts) from the month of January (eight districts) to May (three districts) with maximum decrease in February (15 districts). Not a single district of Maharashtra reported increasing trends in rainfall from the month January to May (except Latur). These changing patterns are very crucial from the agricultural or hydrological point of view. In spite of increasing trends in monsoon rainfall in many areas, the decreasing trends in the first five months of the year have resulted in increase in heating, and may have an effect in the shortage of soil moisture, ground water and lowering the ground water level. Out of 12 months, the month of August has proved to be very good for the state of Maharashtra as most of the districts have shown increasing trend in August rainfall. The other good month is October. Analysis of seasonality index helps to have an idea about the distribution of the rainfall among the months and separate the states in different rainfall regimes. In coastal areas, SI is greater than 1.2 indicating the extreme rainfall regime where almost all the rain occurs in one to two months. Eastern parts 
and western parts (other than coastal regions) have $\mathrm{SI}$ in between 1 and 1.2 indicating a rainfall regime where most rain occurs in three months or less. The central parts of the state has seasonal rainfall regime having four months of rainy season indicating good for agriculture. The most warning situation for the agriculture and water sectors is the increasing trends in the seasonality index in most of the districts. Spatial analysis of both the trends in monthly total rainfall and trends in seasonality index will help the planners of all sectors depending on rainfall in identifying the zones in Maharashtra for better management and planning.

\section{References}

Adejuwon J O 2012 Rainfall seasonality in the Niger Delta Belt; Nigerian J. Geogr. Reg. Plan. 5(2) 51-60.

Epstein H E, Gill R A, Paruelo J M, Lauenroth W K, Jia G J and Burke I C 2002 The relative abundance of three plant functional types in temperate grasslands and shrublands of North and South America: Effects of projected climate change; J. Biogeogr. 29 875-888.

Finkelstein P L and Truppi L E 1991 Spatial distribution of precipitation seasonality in the United States; J. Climate 4 373-385.

Groisman P, Knight R and Karl T 2001 Heavy precipitation and high stream flow in the contiguous United States: Trends in the twentieth century; Bull. Am. Meteorol. Soc. 82 219-246.

Guhathakurta P and Rajeevan M 2008 Trends in rainfall pattern over India; Int. J. Climatol. 28 1453-1469.
Guhathakurta P, Sreejith O P and Menon P A 2011 Impact of climate change on extreme rainfall events and flood risk in India; J. Earth Syst. Sci. 120(3) 359-373.

Kanellopoulou E A 2002 Spatial distribution of rainfall seasonality in Greece; Weather 57 215-219.

Livada I and Asimakopoulos D N 2005 Individual seasonality index of rainfall regimes in Greece; Climate Res. 28 $155-161$.

Markham C G 1970 Seasonality of precipitation in the United States; Am. Assoc. Am. Geogr. 60 593-597.

Pryor S C and Schoof J T 2008 Changes in the seasonality of precipitation over the contiguous USA; J. Geophys. Res. 113 D21108, doi: 10.1029/2008JD01025.

Rosenberg N J, Brown R A, Izaurralde R C and Thomson A M 2003 Integrated assessment of Hadley Centre (HadCM2) climate change projections on agricultural productivity and irrigation water supply in the conterminous United States. I. Climate change scenarios and impacts on irrigation water supply simulated with the HUMUS model; Agric. For. Meteorol. 117(1-2) 73-96.

Sinharay K C and Srivastava A K 2000 Is there any change in extreme events like drought and heavy rainfall?; Curr. Sci. 79(2) 155-158.

Small D, Islam S and Vogel R M 2006 Trends in precipitation and stream flow in the eastern US: Paradox or perception?; Geophys. Res. Lett. 33 L03403, doi: 10.1029/2005GL024995.

Walsh R P D and Lawer D M 1981 Rainfall seasonality: Description, spatial patterns and change through time; Weather 36 201-208.

Walter M W 1967 Length of the rainy season in Nigeria; Nigeria Geog. J. 10 127-128.

Xiao J and Moody A 2004 Photosynthetic activity of US biomes: Responses to the spatial variability and seasonality of precipitation and temperature; Global Change Biology 10 437-451. 